\title{
CDKL2 wt Allele
}

National Cancer Institute

\section{Source}

National Cancer Institute. CDKL2 wt Allele. NCI Thesaurus. Code C51195.

Human CDKL2 wild-type allele is located in the vicinity of $4 q 21.1$ and is approximately 51 $\mathrm{kb}$ in length. This allele, which encodes cyclin-dependent kinase-like 2 protein, is involved in signaling events that result in T-cell activation. 